\title{
Sustainable Agritourism Based on Resource Based Theory
}

\author{
Ni Luh Henny Andayani ${ }^{1, *}$ Trianasari Trianasari ${ }^{1}$ I Gede Putra Nugraha ${ }^{1}$ \\ ${ }^{1}$ Department of Management, Universitas Pendidikan Ganesha, Singaraja, Indonesia \\ *Corresponding author.Email: luhenny.andayani@gmail.com
}

\begin{abstract}
The massive development of tourist villages is a challenge for community members as managers in their development efforts. Economic, social and cultural sustainability is a challenge and competition is a solution. In a competitive effort, it is necessary to have the right strategy by aligning the supply and demand of a tourist destination with the attractiveness of agrotourism. Based on resource based theory, the idea of identifying internal resources that have the ability to compete. The development of agro-tourism so far has not provided any economic benefits to community members. This is due to their lack of involvement in development activities. Aspects of the study of resources based and entrepreneurship, namely managing resources together. Resource based identifies aspects of entrepreneurial cognition that have competitive capabilities, where homogeneous inputs can become heterogeneous outcomes. By identifying internal resources that cannot be imitated in the long term, destinations will have the ability to compete.
\end{abstract}

Keywords: Sustainability, Community member, Competition, Agritourism.

\section{INTRODUCTION}

Tourist destinations in the world are developing rapidly lately. This is based on its ability to revive the sectors in it, and contribute greatly to the source of foreign exchange earnings, economic growth and the creation of state jobs [1]. Destinations are currently seen as small and medium enterprises because of their ability to offer five main components, namely: attractions, facilities and, accessibility (including transportation), image, brand and perception, and price to visitors [2].

The massive development of villages into tourism destinations is a challenge for rural communities who are dominantly engaged in the agricultural sector. In Bali on 2018 there were 110 tourist villages. Of the 110 tourist villages there are only a few tourist villages that have a high number of tourist visits, such as Penglipuran Village and Jatiluwih Village, while the remaining number of visits is relatively small, as happened in Sibetan Village [3]. It takes the right strategy so that tourist villages have the ability to compete.

Rural areas in Bali in general are still very dependent on the agricultural sector. Tourism and agriculture have an important role because they are able to contribute to local growth [4]. The development of tourism in rural areas (rural tourism) encourages the emergence of alternative agricultural businesses/ alternative farm entrepreneurs (AFE's) such as Agrotourism [5]. Agrotourism is closely related to social and economic motives aimed at preserving agriculture [6] [7]. Agrotourism is also recommended because it produces many benefits for agriculture, operators, surrounding communities, and society as a whole [7].

Studies in rural sociology position Agrotourism as an agricultural enterprise developed to diversify agricultural income [8], as an alternative use of agricultural resources [6], as a strategy for resilience from future uncertainty to sustain agriculture [9], as a strategy for preserving traditional rural landscapes and protect the surrounding environment as well as stimulate sustainable rural development [10], [11]. The development of agro-tourism is also able to make a positive contribution to rural development and sustainable livelihoods [12] and provide alternative income opportunities for farming households [13]. Based on these conditions, it can be said that agrotourism is a form of agricultural diversification.

The form of agro-tourism in Bali in fact has not made a significant contribution, especially to the community. Conditions that occur include: operational development of community-based agro-tourism is 
constrained by the low level of community education and skills, thus making their productivity ineffective [14], farmers are seen as objects rather than subjects of tourism activities [15], an increase in professional transfer from farmers to tourism indsutry [16] and young people are not interested in becoming farmers because the income outside the agricultural sector is greater than the agricultural sector [17].

\section{LITERATURE REVIEW}

The more dynamic the competition in tourist destinations today, so that it is necessary to have resources that are able to win the competition. The resource in question is everything that can be considered as a company's strengths and weaknesses [18]. These resources are tangible and intangible assets tied semipermanently to the company.

The available resources can contribute to a sustainable competitive advantage (SCA) [19]. Organizational resources that are valuable, rare, difficult to imitate, and cannot be replaced. Valuable means that it can be used for company activities, rare means it is owned by only a few companies. Non-copyability means that the resource is protected from being imitated by competitors. Irreplaceable means that the resources are only owned by certain companies and cannot be replaced by other products [20]. These types of resources can lead companies to achieve competitive advantage

Resource based theory, is basically a theoretical framework that studies the resources of a company. The company's resources can be in the form of financial, human, physical facilities, and intangible assets (knowledge) [21] in order to create a competitive advantage and how to gain a sustainable advantage.

In building a competitive advantage, it is necessary to have the right strategy to map various competencies so as to be able to develop superior core competencies. These competencies can be unique capabilities developed by the company in key areas such as quality, service, innovation, flexibility, speed etc. Competitive advantage can be divided into two, namely logisticsbased competitive advantage [22] and resource-based competitive advantage [19]. The approach used in this paper is resource-based on competitive advantage.

\section{RESULTS \& DISCUSSION}

The development of rural areas as a tourism destination is a challenge for community members as destination managers. Community members are required to be able to manage villages and all the potential they have which is analogous to entrepreneurs. [23] expresses the term entrepreneurship, namely: the ability to see where a product (or service) does not exist or unexpectedly appears as something of value, in the sense that homogeneous inputs become heterogeneous outputs that make the company a superior choice in the market [24].

So, what about the readiness of the community members? The tourist village in this paper is analogous to a company, where to maintain its existence, it must have the ability to compete, in order to win the competition. Likewise, with agrotourism, which is one of the concepts of tourism development by utilizing agriculture. It takes the right strategy so that agrotourism can be sustainable.

The current reality is that many agro-tourism destinations in rural areas offer the same attractions, because of the similarity of physical potential in the form of agricultural land, plantations owned by the community. Tourism activities that are currently being developed are also based on the terms observe, imitate and modify (ATM), so that the output produced is relatively the same, for example offering similar activities such as farming, tracking, etc., only differentiated by location. The result is high visits are still dominated by several villages, one of which is Jatiluwih Village, while several other tourist villages such as: Sibetan, Catur, etc. the number of visits is relatively small. Community empowerment in development activities is also still minimal so that the economic benefits are not felt by the people.

Reflecting on the resource-based theory, the sustainability of a destination depends on its internal resources. The resource must be unique so that it is not easily imitated by competitors. The resource-based theory also reveals that heterogeneity is very important. Heterogeneous resources are also a basic requirement in entrepreneurship [24]. So it can be said that resourcebased and entrepreneurship both study resources. Resource-based logic tends to focus on the heterogeneity of resources while entrepreneurship tends to focus on heterogeneity in beliefs about the value of resources [23].

Entrepreneurship has a vital role in economic development and is the engine of the economy [25]. Entrepreneurship is one of the strategies in the development of a country, and is a supporting element in rural tourism development [26]. The success of a destination is strongly influenced by the participation of its people and the existence of entrepreneurs.

Previous research on entrepreneurship has largely ignored the agricultural sector, and the importance of entrepreneurial identity and entrepreneurial orientation [27]. A sustainable bottom-up approach is needed in poverty alleviation efforts by equipping rural farmers with entrepreneurial skills [28]. In fact, what often happens is that their entrepreneurial abilities are less able to respond to the demands of changing markets, 
and have limited opportunities to act strategically, but must take a lot of risks and have little power to influence the food chain [29]. The current reality is that in an effort to quickly develop agro-tourism destinations, bringing in foreign investors is the best solution, so that people do not enjoy the benefits.

So far, the development of community-based agrotourism destinations has not provided full benefits for the community, especially farmers. In an effort to develop sustainable agro-tourism, involving and making farmers as entrepreneurs is not easy. The above conditions are influenced by the limited capacity of the population (community competence) in the agro-tourism area [30], where the average level of formal education is relatively low (elementary school graduates) [14], the lack of participation in various non-formal education activities such as participation in counseling activities and training [31]; and the number of rural residents who are still active in the agricultural sector is generally dominated by the older generation [32].

Farmer regeneration is absolutely necessary in an effort to attract quality resources. Reducing the flow of urbanization to cities becomes a new challenge, which is influenced by push and pull factors. The push factor comes from internal conditions where the agricultural sector does not provide prestige, is at high risk, does not provide guarantees for stability and continuity of income, higher education levels correlate with selective use of job opportunities in rural areas, and most parents do not want their children to become farmers. Pull factors that come from external factors, namely the view that working in non-agricultural jobs is more prestigious, and incentives to work in the nonagricultural sector are higher. For those with higher education, the choice of work in the informal sector is an alternative, such as being a civil servant, or in the industrial sector [32]. The development of agritourism, which collaborates with agriculture with tourism activities, is expected to be a factor in attracting the involvement of young people. Working in the tourism sector is perceived as more prestigious and the incentives are greater. Agritourism development should look at the agricultural sector from the broad agribusiness context, which includes agricultural activities from upstream to downstream, not only on farm activities that are introduced such as working in the hot sun and dirty.

As one entrepreneur knows, it is described as an individual who manages his own business and is willing to take risks, but not everyone can read entrepreneurial opportunities. [33] revealed that the ability to read entrepreneurial opportunities exists mainly because different agents have different beliefs about the relative value of resources when transformed from inputs to outputs, managerial cognitive knowledge can be used to understand why different decisions are taken [24]. Thus entrepreneurship is related to cognition, discovery, pursuing market opportunities, and coordinating knowledge leading to heterogeneous outcomes [24]. Entrepreneurial cognition is defined as the extensive use of heuristics and individual beliefs to influence decision making [24], which is built on limited experience and beliefs. Heuristic-based logic allows entrepreneurs to more quickly understand uncertain and complex situations. [34] revealed that such a decision approach can lead to an insightful approach to seeing new opportunities, faster learning and more innovative interpretations [24].

\section{CONCLUSIONS}

Many farmers are unsuccessful in running an agrotourism business due to a lack of understanding of entrepreneurial concepts and strategies [35] [5]. In fact, if we look more closely at the daily activities of farmers, so far, they have reflected entrepreneurial activities, whether it is how to buy seeds, plant, weed, to sell agricultural products. However, many farmers are not aware of this. Understanding the psychology of farmers and other community members is important to do, in an effort to maintain the existence of agriculture and the sustainability of agro-tourism destinations. Understanding the behavior and its driving factors is one way to find a solution to this condition. Agricultural development activities are not only processes that produce social changes in values, norms, and behavior for the welfare of farmers and society [32], but are also able to minimize the stigma of farmers who are always identified with the poor [36].

\section{REFERENCES}

[1] H. Zang, L. A. Xiaoxiao, and L. L. Chai, "Destination image and tourist loyality: A metaanalysis, Tourist management," vol. 40, pp. 213223, 2014, [Online]. Available: https://doi.org/10.1016/j.tourman.2013.06.006.

[2] M. Soteriades, "Tourism destination marketing: approaches improving effectiveness and efficiency," J. Hosp. Tour. Technol., vol. 3, no. 2, p. 107, 2012, [Online]. Available: https://doi.org/10.1108/17579881211248781.

[3] I. K. Sumantra, A. Yuestuti, and A. K. Sudiana, "Pengembangan model agrowisata salak berbasis masyarakat di desa sibetan," J. Bakti Sar., vol. 4, no. $2,2015$.

[4] Sanches-Pereira A, O. B, P. H, C. ST, G. G. MF, and M. MK, "Fostering local sustainable development in Tanzania by enhancing linkages between tourism and small-scale agriculture," $J$. Clean. Prod., 2017, [Online]. Available: doi: https://doi.org/10.1016/ j.jclepro.2017.06.164 .

[5] N. G. McGehee and K. Kim, "Motivation for agri- 
tourism entrepreneurship," J. Travel Res., vol. 43, no. 2, pp. 161-170, 2004, [Online]. Available: https://doi.org/ 10.1177/0047287504268245.

[6] C. Barbieri and P. . Mshenga, "The role of the firm and owner characteristics on the performance of agritourism farms," Sociol. Ruralis, vol. 48, no. 2, p. $166,2008$.

[7] C. Tew and C. Barbieri, "The perceived benefits of agritourism: The provider's perspective," Tour. Manag., vol. 33, no. 1, pp. 215-224, 2012.

[8] T. Streifeneder, "Agriculture first: Assessing European policies and scientific typologies to define authentic agritourism and differentiate it from countryside tourism," Tour. Manag. Perspect., vol. 20, pp. 251-264, 2016.

[9] I. Potočnik-Slavič and S. Schmitz, "Farm Tourism Across Europe," Eur. Countrys., pp. 265-274, 2013, [Online]. Available: https://doi.org/10.2478/euco-2013-0017.

[10] S. Malkanthi and J. Routry, "Potential for agritourism development: Evedance from Sri Lanka," J. Agric. Sci. - Sri Lanka, vol. 6, no. 1, pp. 45-48, 2011, [Online]. Available: http://doi.org/10.4038/jas.v6i1.3812.

[11] C. Barbieri, "Agritourism research: A perspective article," Tour. Rev., 2019.

[12] M. C. Stanciu, "Aspects of sustainable rural tourism - farmers' markets and farm visits," Sci. Pap. Ser. Manag. Econ. Eng. Agric. Rural Dev., vol. 15 , no. $4,2015$.

[13] T. Kizos, "Multifunctionality of farm households in Greece Norsk Geografisk Tidsskrift," Nor. J. Geogr., vol. 64, no. 2, pp. 105-116, 2010.

[14] I. P. D. Swastika, M. K. S. Budhi, and M. H. . Dewi, "Analisis pengembangan agrowisata untuk kesejahteraan masyarakat di Kecamatan Petang, Kabupaten Badung," E-Jurnal Ekon. Dan Bisnis Univ. Udayana, vol. 6, no. 12, pp. 4103-4136, 2017.

[15] I. G. Pitana and P. G. Gayatri, Sosiologi Pariwisata. Yogyakarta: Andi, 2005.

[16] G. Aryawan, I. M. Sara, and A. A. S. Purnami, "The role of stakeholders in agro-tourism development with mactor analysis approach (case study in catur tourism village of bali province, indonesia)," SSRG Int. J. Econ. Manag. Stud., vol. 6, no. $11,2019$.

[17] A. . Nugroho, L. R. Waluyati, and Jamhari, "Upaya Memikat Generasi Muda Bekerja pada Sektor Pertanian di Daerah Istimewa Yogyakarta," JPPUMA J. Ilmu Pemerintah. dan Sos. Polit. $U M A$, vol. 6, no. 1, pp. 76-95, 2018.

[18] B. Wernerfelt, "A Resource-Based View of The
Firm," Strateg. Manag. J., vol. 5, no. 2, pp. 171180, 1984.

[19] J. Barney, "Firm Resources and Sustained Competitive Advantage," J. Manage., vol. 17, no. 1, pp. 99-120, 1991, [Online]. Available: https://doi.org/10.1177/014920639101700108.

[20] J. B. Barney, "Is the resource-based 'view' a useful perspective for strategic management research? Yes," Acad. Manag. Rev., vol. 26, no. 1, pp. 41-56, 2001, [Online]. Available: https://doi.org/10.5465/amr.2001.4011938.

[21] D. Muharam, "Penerapan konsep resources-based view (RBV) dalam upaya mempertahankan keunggulan bersaing perusahaan," J. ilmu Adm. media Pengemb. ilmu dan Prakt. Adm., vol. 14, p. 82, 2017, [Online]. Available: https://doi.org/10.131113/jia.v14i1.4 .

[22] M. E. Porter, "Technology and competitive advantage," J. Bus. Strategy, vol. 5, no. 3, pp. 60 78, 1985, [Online]. Available: https://doi.org/10.1108/eb039075.

[23] I. M. Kirzner, "Entrepreneurial discovery and the competitive market process: An Austrian approach," J. Econ. Lit., vol. 35, no. 1, pp. 60-85, 1997.

[24] S. A. Alvarez and L. W. Busenitz, "The entrepreneurship of resource-based theory," $J$. Manage., vol. 27, no. 6, pp. 755-775, 2001.

[25] Darwanto, "Peran Entrepreneurship dalam Mendorong Pertumbuhan Ekonomi dan Peningkatan Kesejahteraan Masyarakat,” 2012.

[26] C. Surugiu, "Development of Rural Tourism Through Entrepreneurship," J. Tour., vol. 8, pp. 65-72, 2009.

[27] H. Suvanto, J. K. Niemi, and M. Lähdesmäki, "Entrepreneurial identity and farmers' protein crop cultivation choices," J. Rural Stud., vol. 75, pp. 174-184, 2020.

[28] E. Naminse and J. Zhuang, "Does farmer entrepreneurship alleviate rural poverty in China? Evidence from Guangxi Province," PLoS One, vol. 13, no. 3, 2018, [Online]. Available: https://doi.org/10.1371/journal.pone.0194912.

[29] J. Phillipson, M. Gorton, M. Raley, and A. Moxey, "Treating farms as firms? The evolution of farm business support from productionist to entrepreneurial models," Environ. Plan. C Gov. policy, vol. 22, no. 1, pp. 31-54, 2004.

[30] I. W. Budiasa and I. G. A. A. Ambarawati, "Community based agro-tourism as an innovative integrated farming systemdevelopment model towards sustainable agriculture and tourism in Bali," J. ISSAAS, vol. 20, no. 1, pp. 29-41, 2014. 
[31] Dumasari, "Kewirausahaan Petani Dalam Pengelolaan Bisnis Mikro Di Pedesaan," J. Inov. dan Kewirausahaan, vol. 3, no. 3, pp. 196-202, 2014.

[32] J. . Colton and G. Bissix, "Developing agritourism in Nova Scotia: Issues and challenges," J. Sustain. Agric., vol. 27, no. 1, pp. 91-112, 2005.

[33] J. Schumpeter, The Theory of Economic Development. An Inquiry into Profits, Capital, Credit, Interest and the Business Cycle. Harvard $\mathrm{U}, 1934$.

[34] G. Gavetti and D. Levinthal, "Looking Forward and Looking Backward: Cognitive and Experiential Search," Adm. Sci. Q., vol. 45, pp. 113-137, 2000.

[35] Susilowati, "Fenomena penuaan petani dan berkurangnya tenaga kerja muda serta implikasinya bagi kebijakan pembangunan pertanian," InForum Penelit. Agro Ekon., vol. 34, no. 1, pp. 35-55, 2016.

[36] C. M. Rogerson, “Tourism-Agriculture Linkages In Rural South Africa: Evidence From The Accommodation Sector," J. Sustain. Tour., vol. 20, no. 3, pp. 477-495, 2012, doi: 10.1080/09669582.2011.617825. 